Tersedia Online di http://journal2.um.ac.id/index.php/jmsp/

ISSN Online : 2541-4429

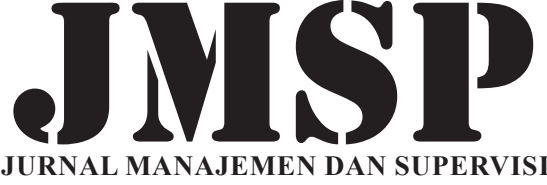

PENDIDIKAN

\title{
EVALUASI PELAKSANAAN PROGRAM GERAKAN LITERASI DI SEKOLAH DASAR
}

\author{
Sitti Roskina Mas, Noval K. Putra Daud, Novianty Djafri \\ Jurusan Manajemen Pendidikan \\ Fakultas Ilmu Pendidikan Universitas Negeri Gorontalo \\ Jl. Jenderal Sudirman No. 6 Kota Gorontalo Indonesia \\ sittiroskina@ung.ac.id
}

\begin{abstract}
This research aimed to determine: (1) the context of school literacy movement programs implementation, (2) the input of school literacy movement programs implementation, (3) the process of school literacy movement programs implementation, and (4) the product obtained from school literacy movement programs implementation in all of public elementary schools in subdistrict of Paguat. The design of this study was an evaluation study using evaluation model of Process and Product Input Context. (PPIC). The technique of data collection used questionnaire and interview. The research results showed that: (1) the context of school literacy movement programs implementation was in good category, (2) the input of school literacy movement programs implementation was in good category, (3) the process of school literacy movement programs implementation was in good category, and (4) the product obtained from school literacy movement programs implementation was in good category. It can be concluded that the evaluation of the school literacy movement programs implementation in all of public elementary schools in subdistrict of Paguat have been carried out properly in terms of the implementation of the activities from the habit stage to the learning stages that have been carried out in accordance with the guidelines of school literacy movement implementation.
\end{abstract}

\section{Keywords: Evaluation; School Literacy Movement}

\begin{abstract}
Abstrak: Penelitian ini bertujuan untuk mengetahui: (1) konteks pelaksanaan program gerakan literasi sekolah, (2) input pelaksanaan program gerakan literasi sekolah, (3) proses pelaksanaan program gerakan literasi sekolah, dan (4) produk pelaksanaan program gerakan literasi sekolah di SD Negeri se Kecamatan Paguat. Desain penelitian ini bersifat studi evaluasi dengan menggunakan model evaluasi Context Input Process and Product (CIPP). Teknik pengumpulan data yang digunakan adalah kuesioner, dan wawancara. Hasil penelitian menunjukan bahwa: (1) konteks dalam pelaksanaan program gerakan literasi sekolah berada pada kategori baik, (2) input dalam pelaksanaan program gerakan literasi sekolah berada pada kategori baik, (3) proses dalam pelaksanaan program gerakan literasi sekolah berada pada kategori baik, dan (4) produk dalam pelaksanaan program gerakan literasi sekolah berada pada kategori baik. Kesimpulan dari hasil penelitian bahwa evaluasi pelaksanaan program gerakan literasi sekolah se Kecamatan Paguat sudah dilaksanakan dengan baik, dilihat dari segi pelaksanaan kegiatan dari tahap pembiasaan sampai dengan tahap pembelajaran telah dilakukan sesuai pedoman pelaksanaan gerakan literasi sekolah.
\end{abstract}

Kata Kunci: Evaluasi; Gerakan Literasi Sekolah

Gerakan Literasi Sekolah (GLS) merupakan program yang dirancang oleh pemerintah pada tahun 2014, dan diberlakukan pada Maret 2016. GLS dilaksanakan pada semua jenjang pendidikan, mulai jenjang Sekolah Dasar, Sekolah Menengah Pertama, dan sekolah Menengah Atas. Pada dasarnya GLS merupakan program untuk menumbuhkan minat baca, sehingga turut serta mengembangkan karakter gemar membaca pada siswa. Lebih spesifik, GLS bertujuan untuk menumbuhkembangkan budi pekerti siswa melalui pembudayaan ekosistem literasi sekolah agar mereka menjadi pembelajaran sepanjang hayat (Kemendikbud, 2016:2). 
Membaca merupakan kemampuan yang harus dimiliki oleh anak karena melaui membaca anak dapat belajar banyak tentang berbagai bidang studi. Oleh karena itu membaca merupakan keterampilan yang harus diajarkan sejak anak masuk Sekolah Dasar (Abdurrahman, 2011). GLS memperkuat gerakan penumbuhan budi pekerti sebagaimana dituangkan dalam Peraturan Menteri Pendidikan dan Kebudayaan Nomor 23 Tahun 2015. Salah satu kegiatan di dalam gerakan tersebut adalah "kegiatan 15 menit membaca buku non pelajaran sebelum waktu belajar dimulai". Kegiatan ini dilaksanakan untuk menumbuhkan minat baca peserta didik serta meningkatkan keterampilan membaca agar pengetahuan dapat dikuasai secara lebih baik.

Kerja sama semua pemangku kepentingan dibidang pendidikan sangat diperlukan untuk melaksanakan gerakan bersama yang terintegrasi dan efektif (Panduan Gerakan Literasi Sekolah di Sekolah Dasar, 2016). Literasi pada dasarnya lebih dari sekedar membaca dan menulis, namun mencakup keterampilan berpikir menggunakan sumber-sumber pengetahuan dalam bentuk cetak, visual, digital, dan auditori. Di era reformasi sedikitnya terdapat tiga jenis literasi yang harusnya dikuasai, jenis literasi tersebut antara lain literasi data, literasi manusia dan literasi teknologi.

Kemampuan membaca siswa di SDN se Kecamatan Paguat berada pada taraf rendah untuk beberapa sekolah yang belum maksimal dalam pelaksanaan yang disebabkan oleh ketersediaan fasilitas yang kurang mendukung, namun dibeberapa sekolah lain kemampuan membaca siswa sudah berada pada taraf normal. Berdasarkan observasi awal yang dilakukkan oleh peneliti, selain memiliki kelebihan program Gerakan Literasi Sekolah juga memiliki kekurangan dalam pelaksanaan program diantaranya: (1) sosialisasi yang kurang, (2) kurangnya tenaga pustakawan profesional, (3) kurangnya ketersediaan media baca, dan (4) sarana dan prasarana yang kurang memadai. Untuk itu peneliti melaksanakan riset tentang evaluasi pelaksanaan program GLS di SD sekecamatan Paguat untuk mengetahui apakah program GLS sudah terlaksana secara optimal atau belum optimal.

Evaluasi secara umum dapat diartikan sebagai suatu proses mencari data atau informasi tentang objek atau subjek yang dilaksanakan untuk tujuan pengambilan keputusan terhadap objek atau subjek tersebut. Menurut (Sukardi (2014). Evaluasi program merupakan evaluasi yang berkaitan erat dengan suatu program atau kegiatan pendidkan, termasuk diantaranya tentang kurikulum, sumber daya manusia, penyelenggara program, proyek penelitian dalam suatu lembaga. Evaluasi sebagai sebuah proses menentukan hasil yang telah dicapai dari beberapa kegiatan yang direncanakan untuk mendukung tercapainya tujuan.

Menurut Sudijono (2015), kegunaan yang dapat dipetik dari kegiatan evaluasi dalam bidang pendidikan adalah : (1) terbukanya kemungkinan bagi evaluator guna memperoleh informasi tentang hasil-hasil yang telah dicapai dalam rangka pelaksanaan program pendidikan, (2) terbukanya kemungkinan untuk dapat diketahuinya relevansi antara program pendidikan yang telah dirumuskan dengan tujuan yang hendak dicapai, dan (3) terbukanya kemungkinan untuk dapat dilakukannya usaha perbaikan, penyesuaian dan penyempurnaan program pendidikan yang dipandang lebih berdaya guna dan berhasil guna, sehingga tujuan yang dicita-citakan akan dapat dicapai dengan hasil yang sebaikbaiknya. Untuk itu perlu memperhatikan langkah-langkah pelaksanaan kegiatan evaluasi.

Langkah-langkah dalam melaksanakan kegiatan evaluasi pendidikan secara umum adalah sebagai berikut: (1) perencanaan (mengapa perlu evaluasi, apa saja yang hendak dievaluasi, tujuan evaluasi, teknik apa yang hendak dicapai, siapa yang hendak di evaluasi, kapan, dimana, penyusunan instrumen, indikator dan apa saja yang hendak digali, (2) pengumpulan data (tes, observasi, kusioer, dan sebagainya sesuai dengan tujuan, (3) verifikasi data (uji instrumen, uji validitas, uji realibilitas), (4) pengolahan data (memaknai data yang terkumpul, kualitatif atau kuantitatif, apakah diolah dengan statistik atau non statistik, apakah dengan para metrik atau non parametrik, apakah dengan manual atau dengan software), (5) penafsiran data, (ditafsirkan melalui berbagai teknik uji, dengan uji hipotesis, ditolak ataupun diterima, jika ditolak mengapa? Jika diterima mengapa? Berapa taraf signifikannya?) interprestasikan data tersebut secara berkesinambungan dengan tujuan evaluasi sehingga akan tampak hubungan sebab akibat. 
Literasi dalam konteks GLS adalah kemampuan mengakses, memahami, dan menggunakan sesuatu secara cerdas melalui berbagai aktivitas, antara lain membaca, melihat, menyimak, menulis, dan berbicara (Kemendikbud, 2016:2). Sebagian besar ilmuwan menganggap literasi sebagai hak asasi warga negara yang wajib difasilitasi oleh setiap Negara. Secara sederhana, literasi adalah kemampuan kemampuan memahami, mengelola, dan menggunakan informasi dalam berbagai konteks (Hartati, 2017).

Kemampuan literasi juga dapat berupa kemampuan menyaring dan mengolah informasi sehingga dapat bermanfaat bagi diri manusia (Nurhasanah, 2016). Dengan demikian dapat disimpulkan bahwa kemampuan literasi terdiri dari kemampuan mengakses, memahami, dan dan memanfaatkan informasi secara cerdas. Menurut Romdhoni (2013), literasi merupakan peristiwa sosial yang melibatkan keterampilan-keterampilan tertentu, yang diperlukan untuk menyimpan dan mendapatkan informasi dalam bentuk tulisan. Keterampilan tersebut dapat berupa keterampilan membaca dan mengamati serta menyimak. Sementara menurut Musfiroh dan Listyorini (2016), literasi memiliki makna dan implikasi dari keterampilan membaca dan menulis dasar ke pemerolehan dan manipulasi pengetahuan melalui teks tertulis, dari analisis metalinguistik unit gramatikal ke struktur teks lisan dan tertulis, dari dampak sejarah manusia ke konsekuensi filosofis dan sosial pendidikan barat.

Kegiatan pelaksanaan pembiasaan gerakan literasi pada tahap ini bertujuan untuk menumbuhkan minat peserta didik terhadap bacaan dan terhadap kegiatan membaca. Pada tahap pembiasaan ini prinsipprinsip kegiatan membaca melliputi : (1) buku yang dibaca/dibacakan adalah buku bacaan, bukan bukuteks pelajaran, (2) buku yang dibaca/dibacakan adalah buku yang diminati oleh peserta didik. Peserta didik diperkenankan untuk membaca buku yang dibawa dari rumah, (3) kegiatan membaca/ membacakan buku di tahap pembiasaan ini tidak diikuti oleh tugas-tugas menghafalkan cerita, menulis sinopsis, dan lain-lain, (4) kegiatan membaca/membacakan buku di tahap pembiasaan inidapat diikuti dengan diskusi informal tentang buku yang dibaca/dibacakan, atau kegiatan yang menyenangkan terkait buku yang dibacakan apabila waktu memungkinkan, dan (5) kegiatan membaca/membacakan buku di tahap pembiasaan ini berlangsung dalam suasana yang santai dan menyenangkan.

Langkah-langkah kegiatan pada tahap pembiasaan meliputi; (1) membaca nyaring; guru/ pustakawan/kepala SD/relawan membacakan buku/bahan bacaan lain dengan nyaring. Tujuannya yaitu; (a) memotivasi peserta didik agar mau membaca, (b) membuat peserta didik dapat membaca dan gemar membaca, (c) memberikan pengalaman membaca yang menyenangkan, (d) membangun komunikasi antara guru dan peserta didik, dan (e) guru/pustakawan/kepala sekolah menjadi teladan membaca. (2) membaca dalam hati; membaca dalam hati (sustained silent reading) adalah kegiatan membaca 15 menit yang diberikan kepada peserta didik tanpa gangguan. Guru menciptakan suasana tenang, nyaman, agar peserta didik dapat berkonsentrasi pada buku yang dibacanya. Adapun tujuannya yaitu untuk Menumbuhkan kebiasaan membaca pada peserta didik (Panduan GLS di SD, 2016).

Kegiatan literasi pada tahap pengembangan bertujuan untuk mempertahankan minat terhadap bacaan dan terhadap kegiatan membaca, serta meningkatkan kelancaran dan pemahaman membaca peserta didik.Prinsip-prinsip kegiatan pada tahap pengembangan meliputi: (1) buku yang dibaca/ dibacakan adalah buku selain buku teks pelajaran, (2) buku yang dibaca/dibacakan adalah buku yang diminati oleh peserta didik. Peserta didik diperkenankan untuk membaca buku yang dibawa dari rumah, (3) kegiatan membaca/membacakan buku di tahap ini dapat diikuti oleh tugas-tugas menggambar, menulis, kriya, seni gerak dan peran untuk menanggapi bacaan, yang disesuaikan dengan jenjang dan kemampuan peserta didik, (4) penilaian terhadap tanggapan peserta didik terhadap bacaan bersifat non-akademik dan berfokus pada sikap peserta didik dalam kegiatan. Masukan dan komentar pendidik terhadap karya peserta didik bersifat memotivasi mereka, (5) kegiatan membaca/membacakan buku berlangsung dalam suasana yang menyenangkan.

Langkah-langkah membaca pada tahap pengembangan yaitu: (1) membacakan nyaring interaktif (interactive read aloud), (2) membaca terpandu (guided reading), (3) membaca bersama (shared reading), dan (4) membaca mandiri (independent reading) (Panduan GLS di SD, 2016). Kegiatan literasi pada tahap pembelajaran bertujuan untuk mempertahankan minat peserta didik terhadap bacaan dan terhadap kegiatan membaca, serta meningkatkan kecakapan literasi peserta didik melalui buku- 
buku pengayaan dan buku teks pelajaran. Kegiatan literasi pada tahap pembelajaran meningkatkan kemampuan berbahasa reseptif (membaca dan menyimak) dan aktif (berbicara dan menulis) yang dijelaskan secara rinci dalam konteks dua kegiatan utama di tahap ini, yaitu membaca dan menulis. Pada tahap ini kegiatan yang dapat dilakukan adalah: (1) guru mencari metode pengajaran yang efektif untuk mendukung kemampuan literasi, (2) guru mengembangkan RPS, (3) guru melaksanakan pembelajaran dengan memaksimalkan pemanfaatan sarana dan prasarana literasi untuk memfasilitasi pembelajaran, (4) guru menerapkan berbagai strategi membaca untuk meningkatkan pemahaman peserta didik terhadap materi pembelajaran (Panduan GLS di SD, 2016).

\section{METODE}

Penelitian ini dikategorikan sebagai penelitian evaluasi. Pada penelitian ini peneliti menggunakan pendekatan studi evaluatif dengan menggunakan model evaluasi CIPP berdasarkan pada kriteria yang telah ditetapkan dalam pelaksanaan GLS di Sekolah Dasar. Penelitian ini juga akan mendeskripsikan masalah yang berkaitan dengan pelaksanaan program GLS di SDN se Kecamatan Paguat.

Subjek dalam penelitian ini adalah kepala sekolah dan guru yang terlibat dalam pelaksanaan program GLS di SDN se Kecamatan Paguat. Penentuan subyek penelitian menggunakan teknik purposive sampling. Sedangkan penentuan sampel sekolah yang menjadi lokasi penelitian menggunakan cluster sampling dengan mempertimbangkan tiga kriteria yaitu instrumen kriteria evaluasi disusun dan dikembangkan berdasarkan indikator dari pelaksanaan program GLS indikator tersebut antara lain: (1) pelaksanaan program pada tahap pembiasaan, (2) pelaksanaan program pada tahap pengembangan, dan (3) pelaksanaan program pada tahap pembelajaran. Teknik pengumpulan data yang digunakan yaitu kuesioner, wawancara dan dokumentasi. Kemudian data yang diperoleh dianalisis secara statistik menggunakan rumus presentase (\%) skor capaian responden, dengan formulasi yang dikemukakan oleh Sudjana (2005:47) yaitu $\operatorname{Pr}=\mathrm{f} / \mathrm{n} \times 100 \%$ dan mencari rata-rata menggunakan rumus $\mathrm{Pr}=\mathrm{SA} / \mathrm{SI} \times 100 \%$.

\section{HASIL DAN PEMBAHASAN}

Hasil penelitian ini mendeskripsikan tentang pelaksanaan program gerakan literasi sekolah yang meliputi: (1) konteks dalam pelaksanaan GLS, (2) input dalam pelaksanaan GLS, (3) proses dalam pelaksanaan GLS, dan (4) produk dalam pelaksanaan GLS. Rata-rata hasil analisis data pelaksanaan program GLS berada pada kualifikasi baik dengan perolehan hasil presentasi $82,26 \%$ yang dapat dilihat pada Tabel 1 berikut ini.

Tabel 1. Hasil Rekapitulasi Evaluasi Komponen Konteks, Input, Proses dan Produk Penelitian

\begin{tabular}{ccccc}
\hline No & $\begin{array}{c}\text { Komponen } \\
\text { Evaluasi }\end{array}$ & $\begin{array}{c}\text { Rata-rata } \\
\text { Skor Capaian }\end{array}$ & $\begin{array}{c}\text { Rata-rata Presentasi } \\
(\%)\end{array}$ & Klasifikasi \\
\hline 1 & Konteks & 109,66 & 85,67 & Baik \\
2 & Input & 102,25 & 79,87 & Baik \\
3 & Proses & 105,23 & 82,28 & Baik \\
4 & Produk & 104 & 81,25 & Baik \\
\hline & Rata-rata & $\mathbf{1 0 5 , 3 0}$ & $\mathbf{8 2 , 2 6}$ & Baik \\
\hline
\end{tabular}

\section{Komponen Konteks Evaluasi Pelaksanaan Program GLS di SDN se Kecamatan Paguat}

Hasil evaluasi komponen konteks pelaksanaan gerakan literasi sekolah memperoleh presentasi 86 $\%$ dengan kualifikasi baik. Hal ini menunjukan bahwa pelaksanaan gerakan literasi sekolah di SD Negeri se Kecamatan Paguat sudah melalui perencanaan yang matang oleh pemerintah pusat dan pemerintah daerah, hal ini terbukti dengan tertuangnya kebijakan yang jelas mengenai pelaksanaan program.

Hal ini sejalan dengan hasil penelitian Wandasari (2017), mengemukakan bahwa secara teknis 
mengembangkan suatu kebijakan di suatu sekolah yang "sehat" bukanlah suatu hal yang terlampau sukar. Ide tentang gerakan literasi sekolah seperti ini merupakan suatu keharusan yang perlu diketahui oleh tenaga-tenaga pendidik agar dapat mendukung suatu kebijakan di sekolah. Pertumbuhan suatu kebijakan seperti gerakan literasi sekolah tentu saja memerlukan waktu. Kebijakan semacam ini tidak dapat ditegakkan dalam waktu satu bulan atau satu tahun. Karena proses transformasi sekolah itu sendiri juga merupakan suatu proses yang membutuhkan waktu. Konteks gerakan literasi sekolah sebagai upaya menanamkan budaya literasi siswa Indonesia yang dikemukakan pada bagian hasil diatas telah memberi indikasi kuat bahwa pemilihan gerakan literasi sekolah sebagai upaya menanamkan budaya literasi siswa Indonesia tepat adanya.

Berdasarkan hasil analisis dan temuan penelitian diatas, dapat disimpulkan bahwa pelaksanaan gerakan literasi sekolah membutuhkan dukungan kolaboratif dari berbagai elemen. Adapun program ini didasarkan pada tiga tahapan, dimana pada tahap pembiasaan dilakukan kegiatan 15 menit membaca buku sebelum pelajaran dimulai. Kegiatan ini dilaksanakan untuk menumbuhkan minat baca peserta didik serta meningkatkan keterampilan membaca agar pengetahuan dapat dikuasai secara lebih baik. Kemudian siswa diarahkan pada tahap pengembangan dan tahap pembelajaran dengan berbagai metode dan pendekatan membaca yang dikolaborasikan pada pembelajaran.

\section{Komponen Input Evaluasi Pelaksanaan Program GLS di SDN se Kecamatan Paguat}

Hasil evaluasi komponen input pada penelitian ini berkategori baik dengan prosentasi $80 \%$. Hal ini menunjukkan bahwa komponen input sudah berada di atas taraf rata-rata, sekolah sudah melakukan hal-hal yang sesuai terkait hal-hal yang menjadi input dalam pelaksanaan program yang tercantum dalam petunjuk teknis yang ada. Namun perlu adanya peningkatan kapasitas SDM yang memiliki kemampuan dalam mengelola dan melaksanakan kegiatan gerakan literasi sekolah secara maksimal dan berkesinambungan.

Komponen evaluasi input (evaluasi masukan), meliputi: (1) sumber daya manusia, (2) sarana dan prasarana pendukung, (3) dana atau anggaran, dan (4) berbagai prosedur dan aturan yang diperlukan. Menurut hasil penelitian Wandasari (2017) input dalam gerakan literasi sekolah merupakan suatu usaha atau kegiatan yang bersifat partisipatif dengan melibatkan warga sekolah (peserta didik, guru, kepala sekolah, tenaga kependidikan, pengawas sekolah, komite sekolah, orang tua/wali murid peserta didik), akademisi, penerbit, media massa, masyarakat (tokoh masyarakat) yang dapat merepresentasikan keteladanan, dunia usaha, dan pemangku kepentingan di bawah koordinasi Direktorat Jenderal Pendidikan Dasar dan Menengah Kementerian Pendidikan dan Kebudayaan. Gerakan Literasi Sekolah adalah gerakan sosial dengan dukungan kolaboratif berbagai elemen.

Berdasarkan penjelasan diatas, dapat disimpulkan bahwa komponen input pada pelaksanaan gerakan literasi sekolah merupakan hal yang penting bagi berlangsungnya suatu proses. Input dalam pelaksanaan gerakan literasi sekolah meliputi sumber daya manusia dan sarana prasarana pendukung untuk keberhasilan dalam pelaksanaan program.

\section{Komponen Proses Evaluasi Pelaksanaan Program GLS di SDN se Kecamatan Paguat}

Hasil penelitian menunjukkan bahwa evaluasi komponen proses berada pada kategori baik dengan prosentasi $82 \%$, artinya pelaksanaan program gerakan literasi sekolah yang dibuat oleh pemerintah sudah berjalan sesuai dengan ketentuan meskipun masih banyak hal yang perlu dibenahi dan menjadi perrhatian bagi seluruh elemen terkait. Sehubungan dengan itu maka program ini tentunya menjadi salah satu terobosan pemerintah dalam mencapai gerakan literasi Indonesia dalam mewujudkan masyarakat Indonesia yang gemar membaca.

Pada dasarnya evaluasi proses dilakukan untuk mengetahui bagaimana rencana telah diterapkan dan komponen apa yang perlu diperbaiki. Dimulai dari peran guru dalam melaksanakan kegiatan program budaya membaca di sekolah sangatlah dibutuhkan agar nantinya siswa benar-benar paham dan mengaplikasikan dalam kehidupan sehari-hari. Hal ini sejalan dengan temuan pada penelitian yang dilakukan oleh Sulistyo (2017), bahwa guru merupakan komponen yang sangat mendukung peningkatan kemampuan membaca siswa terutama pada program literasi. Kurangnya komitmen 
guru dalam melaksanakan kegiatan-kegiatan program budaya membaca, terutama pada kegiatan yang bersifat rutinitas yaitu pada kegiatan membaca 15 menit sebelum kegiatan pembelajaran dan kegiatan merangkum. Pada kegiatan membaca 15 menit sebelum pembelajaran belum berjalan sesuai dengan jadwal, kendala yang dihadapi adalah beberapa guru belum hadir saat kegiatan berlangsung sehingga banyak kelas yang tidak tertunggui, akibatnya kegiatan membaca 15 menit terhambat pada pelaksanaannya.

\section{Komponen Produk Evaluasi Pelaksanaan Program GLS di SDN se Kecamatan Paguat}

Hasil dari komponen produk pada penelitian ini berada dalam kualifikasi baik dengan ratarata presentasi $81 \%$. Hal ini menunjukkan bahwa pelaksanaan program gerakan literasi sekolah berada dikategori baik, terbukti dengan terciptanya proses pelaksanaan program yang nyaman dan menyenangkan. Dengan perolehan hasil presentasi berada pada kualifikasi baik, maka pelaksanaan program gerakan literasi sekolah dapat dilanjutkan untuk tahun berikutnya dengan lebih baik lagi dan memperhatikan ketentuan-ketentuan yang telah ditetapkan agar tujuan literasi dapat tercapai secara efektif.

Hal ini sejalan Faizah (2016), tujuan literasi ada empat yaitu sebagai berikut; (1) menumbuhkan dan mengembangkan budaya literasi sekolah, (2) meningkatkan kapasitas warga dan lingkungan sekolah agar literat, (3) menjadikan sekolah sebagai taman belajar yang menyenangkan dan ramah agar warga sekolah mampu mengelola pengetahuan, dan (4) menjaga keberlanjutan pembelajaran dengan menghadirkan beragam buku bacaan di sekolah dan mewadahi berbagai strategi membaca. Evaluasi produk merupakan penilaian yang dilakukan guna untuk melihat ketercapaian/ keberhasilan suatu program dalam mencapai tujuan yang ditentukan sebelumnya. Menurut hasil penelitian Sulistyo (2017:56) hasil yang didapatkan dari evaluasi produk adalah keuntungan pelaksanaan program budaya membaca mampu untuk membaca dan menulis secara lancar sehingga mampu membantu siswa dalam meningkatkan prestasi belajar, siswa gemar membaca dan menulis, tercipta suasana belajar yang menyenangkan dan menumbuh kembangkan budaya literasi di sekolah.

Dari hasil evaluasi keseluruhan komponen mulai dari komponen konteks, input, proses dan produk pelaksanaan program gerakan literasi sekolah di SD Negeri se Kecamatan paguat memperoleh presentasi $82 \%$ dengan kualifikasi baik. Menurut Depdiknas (dalam Idrus, 2014), bahwa jika presentasi berada pada rentang 71-100 \% berarti berada pada kualifikasi tinggi artinya program tersebut sudah berhasil dengan baik maka sangat baik lagi jika program ini terus dikembangkan dan diperbaiki dalam pelaksanaannya, ditunjang dengan sarana prasarana yang memadai serta dibutuhkan kemampuan guru yang optimal.

\section{SIMPULAN DAN SARAN}

\section{Simpulan}

Hasil evaluasi pelaksanaan program GLS di SDN se- Kecamatan Paguat adalah sebagai berikut: (1) hasil evaluasi konteks pada pelaksanaan program GLS berada pada kualifikasi baik, hal ini menunjukkan bahwa evaluasi konteks penelitian yang mencakup kebijakan pada tahap pembiasaan, kebijakan pada tahap pengembangan dan kebijakan pada tahap pembelajaran sudah berada pada kualifikasi baik, (2) hasil evaluasi komponen input pada pelaksanaan program GLS berada pada kualifikasi baik. Hal ini menunjukkan bahwa identifikasi kesiapan sekolah, pelaksanaan tahap pembiasaan, pelaksanaan tahap pengembangan, dan pelaksanaan tahap pembelajaran sudah sesuai dengan ketentuan, sehingga apa yang menjadi tahap berikutnya dalam pelaksanaan program gerakan literasi sekolah ini dapat berjalan dengan lancar, karena komponen input merupakan titik awal suatu kegiatan akan dilaksanakan, (3) hasil evaluasi komponen proses pelaksanaan program GLS berada pada kualifikasi baik. Hal ini menunjukkan bahwa pelaksanaan tahap pembiasaan, pelaksanaan tahap pengembangan, dan pelaksanaan tahap pembelajarean sudah sesuai dengan alur dan petunjuk pelaksanaan untuk mencapai tujuan yang telah ditetapkan, dan (4) hasil evaluasi komponen produk pelaksanaan GLS berada pada kualifikasi baik. Hal ini menunjukkan bahwa hasil pelaksanaan program tahap pembiasan, tahap pengembangan, dan tahap 
pembelajaran sudah mencapai tujuan yang diharapkan, sehingga untuk pelaksanaan program GLS pada tahun berikutnya diupayakan dapat dilaksanakan secara optimal dan berjalan sesuai dengan ketentuan.

\section{Saran}

Agar kegiatan GLS berjalan efektif maka peneliti menyarankan: (1) bagi Kepala Dinas Pendidikan Pohuwato diharapkan dapat memaksimalkan sarana prasarana penunjang GLS untuk terwujudnya GLS yang efektif di seluruh sekolah binaannya, (2) bagi kepala sekolah hendaknya menyediakan sudut baca yang memadai, mengalokasikan waktu untuk membiasakan siswa membaca agar tercipta budaya baca di sekolah ataupun di luar sekolah, dan (3) bagi guru, disarankan untuk dapat menerapkan berbagai metode dan strategi membaca untuk meningkatkan budaya baca siswa. Di samping itu diharapkan juga guru meningkatkan kemitraan dengan orang tua, masyarakat yang berkompeten, dengan melibatkannya dalam kegiatan GLS karena bukan hanya guru yang bertanggung jawab dalam pendidikan tetapi orang tua, dan masyarakat juga bertanggung jawab dalam penyelenggaraan pendidikan khususnya dalam kegiatan GLS.

\section{DAFTAR RUJUKAN}

Abdurrahman, M. 2011. Anak Berkesulitan Belajar Teori, Diagnosis, dan Remediasinya. Jakarta: Rineka Cipta.

Faizah, D.U., et al. 2016. Panduan Gerakan Literasi Sekolah di Sekolah Dasar. Jakarta: Direktorat Jenderal Pendidikan Dasar dan Menengah Kementerian Pendidikan dan Kebudayaan.

Hartati, T. 2017. Multimedia in Literacy Development at Remote Elementary Schools in West Java (Multimedia Dalam Pengembangan Literasi Di Sekolah Dasar Terpencil Jawa Barat). Edutech. Volume: 15 Issue: 3 Page: 301-310.

Idrus, M. 2014. Metode Penelitian Ilmu Sosial. Yogyakarta: PT. Gelora Aksara Pratama.

Kemendikbud. 2016. Panduan GLS di Sekolah Dasar. Jakarta: Direktorat Jenderal Pendidikan Dasar dan Menengah.

Kusuma, M. 2016. Evaluasi Pendidikan: Pengantar, Kompetensi, dan Implementasi. Yogyakarta: Parama Ilmu.

Musfiroh, T. \& Listyorini, B. 2016. Konstruk Kompetensi Literasi untuk Siswa Sekolah Dasar. Jurnal Litera. Volume: 15 Halaman: 1-12.

Nurhasanah, A. 2016. Penggunaan Metode Simulasi dalam Pembelajaran Keterampilan Literasi Informasi IPS bagi Mahasiswa PGSD. Jurnal Pendidikan Sekolah Dasar. Volume 2 Nomor 1 Halaman 87-95.

Panduan Gerakan Literasi Sekolah di Sekolah Dasar Tahun 2016.

Peraturan Menteri Pendidikan dan Kebudayaan Nomor 23 tahun 2015 Tentang Penumbuhan Budi Pekerti.

Romdhoni, A. 2013. Al-Qur'an dan Literasi. Depok: Literatur Nusantara.

Sudijono, A. 2015. Pengantar Evaluasi Pendidikan. Jakarta: PT Rajagrafindo Persada.

Sudjana, N. \& Ibrahim. 2004. Penelitian dan Penilaian Pendidikan. Bandung: Sinar Baru Algesindo.

Sukardi. 2014. Evaluasi Program Pendidikan dan Kepelatihan. Jakarta: PT Bumi Aksara.

Sulistyo, A. 2017. Evaluasi Program Budaya Membaca di Sekolah Dasar Negeri Kelola. Jurnal Manajemen Pendidikan. Volume: 4 Nomor: 1 Halaman: 48-58.

Wandasari, Y. 2017. Implementasi Gerakan Literasi Sekolah (GLS) Sebagai Pembentuk Pendidikan Berkarakter. JMKSP (Jurnal Manajemen, Kepemimpinan, dan Supervisi Pendidikan). Volume: 2 Nomor: 2. 